\title{
П.М. Евлоева
}

Первый Московский государственный медицинский университет им. И.М. Сеченова, Российская Федерация Центр охраны материнства и детства, Назрань, Российская Федерация

\section{Медико-демографическая ситуация в Чеченской Республике и Республике Ингушетия в 2005-2010 гг.}

Контактная информация:

Евлоева Пятимат Магомедовна, аспирант НИИ общественного здоровья и управления здравоохранением ГБоУ ВПо «Первый МГмУ им. И.М. Сеченова", заместитель главного врача по организационно-методической работе ГУ "Центр охраны здоровья матери и ребенка" г. Назрани Адрес: 366000, Назрань, ул. Муталиева, д. 66, тел.: (8732) 22-14-84, e-mail: evloeva-f-m@mail.ru Статья поступила: 31.05.2012 г., принята к печати: 05.10.2012 г.

Политическая и социально-экономическая дестабилизация, военные конфликты и отсутствие инфраструктуры, массовые миграционные потоки сформировали существующую медико-демографическую ситуацию в Чеченской Республике и Республике Ингушетия: здесь имеет место высокий уровень рождаемости и фертильности, превышающий в 2 и более раз аналогичный показатель по России. Вместе с тем зафиксированы и высокие показатели младенческой смертности, фетоинфантильных потерь. Высокая фертильность приводит к избыточному народонаселению, низкому подушевому доходу, снижению соматического и репродуктивного здоровья женщин и детей, закономерному росту репродуктивных потерь. Способствуют этому и "постарение" рождаемости (в Республике Ингушетия), низкий уровень образования (характерно для Чечни в связи с вступлением в детородный возраст "детей войны"), несоблюдение оптимального интергенетического периода. Анализ состояния здоровья беременных, рожениц и родильниц, новорожденных показывает, что по многим показателям оно хуже, чем в среднем по России. Фетоинфантильные потери в Чеченской Республике и Республике Ингушетия в 2 и более раз выше, чем по Российской Федерации в целом. Одним из важнейших условий для улучшения здоровья женщин репродуктивного возраста и потомства является повышение эффективности работы службы родовспоможения и детства в обеих республиках, планирование семьи.

Ключевые слова: рождаемость, фертильность, фетоинфантильные потери, младенческая смертность, репродуктивное здоровье, "постарение" рождаемости, интергенетический период, планирование семьи, служба родовспоможения и детства.

(Вопросы современной педиатрии. 2012; 11 (5): 12-18)

\section{ВВЕДЕНИЕ}

Чеченская республика (ЧР) и Республика Ингушетия (РИ) входят в состав Северо-Кавказского федерального округа. По данным Госкомстата ЧР, на 01.01.10 г. в ЧР проживало 1268042 человек, в РИ - 516693. Доля детей в возрасте от 0 до 17 лет от общей численности населения в ЧР составляла $35 \%$, что в 2 раза превыша- ет аналогичный показатель по Российской Федерации (РФ) (18,1\%, по данным Министерства здравоохранения и социального развития РФ, 2010). В РИ проживает 145068 детей указанного возраста, что составляет $28 \%$ от всего населения (в 1,5 раза выше среднефедерального показателя). Военно-террористические мероприятия на территории ЧР и практически полное

\section{P.M. Evloeva}

I.M. Sechenov First Moscow State Medical University, Russian Federation The Centre of Maternity and Child Protection, Nazran, Russian Federation

\section{Medico-demographic situation in the Republics of Chechnya and Ingushetia in 2005-2010}

Political and socio-economical destabilization, military conflicts, lack of infrastructure and massive migratory movements formed a current medico-demographic situation in the Republics of Chechnya and Ingushetia: the fertility and birth rates here are very high and exceeds twice the same figures all over the Russian Federation. At the same time the infant mortality and feto-infantile losses rates are also very high. The high fertility leads to overpopulation, low per capita income, worsening of somatic and reproductive women's and children's health and consistent increase of reproductive losses. The aging of fertility (in the Republic of Ingushetia) and the low level of education (which is typical of the Republic of Chechnya due to the "children of war" achievement of childbearing age) and inobservance of optimal intergenetic interval contribute to the aforesaid phenomena. The analysis of pregnant women, women in labour and newborn children state of health shows that according to many characteristics it is worse than at the average in Russia. Feto-infantile losses in the Republics of Chechnya and Ingushetia are more than twice as high as in all over the Russian Federation. One of the most important conditions for the improvement of child-bearing age women and their children is increase of the efficacy of obstetrics and pediatric services in both Republics and family planning.

Key words: birth rate, fertility, feto-infantile losses, infant mortality, reproductive health, aging of fertility, intergenetic interval, family planning, obstetrics and pediatric service.

(Voprosy sovremennoi pediatrii - Current Pediatrics. 2012; 11 (5): 12-18) 
разрушение инфраструктуры, массовые миграционные потоки, политическая дестабилизация привели к крайне низкому социально-экономическому уровню населения, высокому уровню безработицы и дотационности республиканского бюджета, а также к неблагополучной экологической ситуации. РИ после распада Чечено-Ингушской Республики создавалась в неравных стартовых условиях с другими регионами, на базе 3 аграрных районов; практически вся инфраструктура и республиканские специализированные лечебные учреждения остались в Чечне. Специфика Ингушетии заключалась также в том, что она являлась приграничным с 2 зонами военных конфликтов регионом, и в результате притока мигрантов из 2 республик - Северной Осетии и Чечни - численность населения республики увеличилась втрое, что обусловило крайне высокую его плотность.

В настоящее время в ЧР восстановлены и функционируют все республиканские и специализированные лечебные учреждения, однако сельское здравоохранение восстановлено не полностью и отстает от такового в других регионах РФ. В РИ многие лечебно-профилактические учреждения, включая единственную детскую поликлинику, не имеют собственных зданий и находятся в арендуемых приспособленных помещениях, отсутствует детская больница. В обеих республиках имеет место острый дефицит педиатрических кадров, специалистов узкого профиля.

Наиболее важными факторами, формирующими медико-демографическую ситуацию государства, являются социальные. Для ЧР и РИ является традиционным активное репродуктивное поведение населения, чем и обусловлены наиболее высокие по РФ естественные воспроизводственные характеристики, включая рождаемость и естественный прирост населения.

Цель исследования: оценить существующую медикодемографическую ситуацию в ЧР и РИ, проанализировать состояние здоровья беременных, рожениц, родильниц и новорожденных, а также определить условия, необходимые для улучшения здоровья женщин репродуктивного возраста и их потомства.

\section{ПАЦИЕНТЫ И МЕТОДЫ}

\section{Участники исследования}

Всего было опрошено по 1100 матерей в ЧР и РИ с марта по декабрь 2009 г. Базами для проведения исследования послужили детские амбулаторнополиклинические учреждения сельских районов и городов обеих республик.

\section{Методы исследования}

Для оценки динамики основных медико-демографических показателей были использованы данные ежегодных отчетов и сборников статистических данных Министерств здравоохранения ЧР и РИ и Минздравсоцразвития РФ, Росстата РФ и ГКС РИ. Для оценки заболеваемости детей первого года жизни применяли отчетные формы 31/y «Сведения о медицинской помощи детям и подросткам-школьникам" за 2005-2009 гг. Проведено также медико-социологическое исследование: анкетный опрос среди матерей, имеющих практически здоровых детей в возрасте 12-24 мес.

\section{Статистическая обработка данных}

Статистическая обработка фактического материала выполнялась с применением прикладной статистической программы SPSS, версия 17. Использовали методы описательной (дескриптивной) и аналитической статистики. Также был проведен анализ отчетных форм 097/у “История новорожденного", 112/у “История развития ребенка" и 003/y "Медицинская карта стационарного больного" детей ЧР и РИ, умерших на первом году жизни. В исследование были включены младенцы, умершие в 2009 г.: в ЧР - 242 случая смерти (37,5\% от всех умерших младенцев), в РИ - 137 случаев (96,4\% от всех умерших младенцев). Для обеспечения стандартизованного сбора данных использовали анкеты SDS (США), модифицированные экспертными группами ЧР и РИ.

\section{РЕЗУЛЬТАТЫ И ОБСУЖДЕНИЕ}

Естественный прирост населения составлял в ЧР по годам 22,4-21,9 на 1000 человек населения, В РИ - 11,8-14,6. В РФ имел место отрицательный прирост населения, показатели которого колебались от $-5,9$ до -1,8. Общая смертность в ЧР находилась в пределах 4,7-5,1 на 1000 населения, в РИ - 4,5-3,7 (в РФ - 16,1-14,2). ЧР является лидером в России по показателю рождаемости. Средний показатель рождаемости за 6 лет в ней составил 26,6 на 1000 населения, превышая в 2 и более раз аналогичный показатель по РФ и в 1,3 - по РИ. В РИ показатель рождаемости выше, чем по РФ, в 1,6 раз (табл. 1).

Среднегодовой прирост рождаемости в ЧР составлял 2,3. В динамике, с 2005 по 2008 г., в РИ была зафиксирована убыль рождаемости, связанная с оттоком мигрантов в Чечню, соответственно, она пропорционально возросла в Чечне в связи с их возвращением на родину. В РИ в 2009 г. начался скачкообразный рост показателя рождаемости, и среднегодовой прирост составил в 2009 г. 3,8, а в $2010-2,5$, что связано с социально-демографической политикой государства и выдачей средств материнского (семейного) капитала, реализуемых в Ингушетии с 2009 г.

Коэффициент фертильности (плодовитости) на 1000 женщин детородного возраста (15-49 лет) является более информативным и достоверным показателем интенсивности деторождения, чем коэффициент рождаемости, и зависит от многих факторов: возраста, вероисповедания, образовательного уровня, моральных представлений и других факторов. Коэффициент фертильности у женщин в ЧР составляет 86,2 (средний за 6 лет, 2005-2010), он в 1,7 раза выше, чем в РИ $(50,8)$, и вдвое превышает показатель по РФ (в целом

Таблица 1. Рождаемость в Чеченской Республике и Республике Ингушетия за 2005-2010 гг.

\begin{tabular}{|l|c|c|c|c|c|c|}
\hline & $\mathbf{2 0 0 5}$ & $\mathbf{2 0 0 6}$ & $\mathbf{2 0 0 7}$ & $\mathbf{2 0 0 8}$ & $\mathbf{2 0 0 9}$ & $\mathbf{2 0 1 0}$ \\
\hline Российская Федерация & 10,2 & 10,4 & 11,3 & 12,1 & 12,4 & 12,5 \\
\hline Чеченская Республика & $\mathrm{X}$ & 22,3 & 27,1 & 29,3 & 27,0 & 27,5 \\
\hline Республика Ингушетия & 16,3 & 14,3 & 14,2 & 14,5 & 18,3 & 20,8 \\
\hline
\end{tabular}

Примечание. Х - в 2005 г. в Чеченской Республике не велся статистический учет, в связи с чем отсутствуют медикодемографические данные. 
по РФ данный показатель найден в доступных источниках только за 2007 г. и равен 41,4; табл. 2). В Чечне четко прослеживается тенденция к прогрессивному росту показателя фертильности в течение 5 последних лет, что связано с постепенной стабилизацией социальнополитической ситуации в республике и демографической политикой российского государства по стимулированию рождаемости. В РИ также отмечался рост показателя с 2005 (46,0\%о) по 2009 г. (58,7\%о), однако с 2010 г. наметилась тенденция к его снижению.

Однако оценка эффективности репродуктивного процесса только по числу рожденных детей без учета качества родившихся детей и репродуктивных потерь создает иллюзию благополучия рождаемости. В результате избыточного увеличения народонаселения, связанного с неконтролируемой рождаемостью, растет уровень бедности, ухудшаются жизненные условия всех слоев населения (вследствие безработицы, снижения уровня доходов и реальной заработной платы и т.д.), что очень актуально для Ингушетии и Чечни. Фертильность оказывает значительное влияние на соматическое и репродуктивное здоровье женщин и детей. Высокие показатели фертильности в регионах с низким подушевым доходом населения сопровождаются закономерным ростом репродуктивных потерь, снижением жизнеспособности потомства [1, 2].

В медико-демографических исследованиях установлено, что возраст матери при рождении ребенка, интервалы между родами, применение контрацепции, а также длительность грудного вскармливания напрямую влияют на выживаемость матерей и детей, на показатели материнской, младенческой и перинатальной смертности, а также на состояние здоровья матери и ребенка [3].

Одним из важнейших факторов, определяющих фертильность и влияющих на состояние здоровье плода, новорожденного и мать, является возраст женщины $[3,4]$. Проведенное в ЧР и РИ медико-социологическое исследование распространенности и длительности грудного вскармливания (2009-2010) позволило установить, что средний возраст матерей в ЧР был достоверно выше по селу и составлял в среднем 27,4 года, тогда как по городу $-25,8$ лет $(p<0,001)$. В РИ возраст сельских и городских женщин был одинаков и в среднем состав- лял 28,5 лет. Минимальный возраст матерей в ЧР -15 , в РИ - 17 лет, максимальный в ЧР - 48, в РИ - 45 лет (табл. 3). Обращают на себя внимание значительные различия в репродуктивном поведении женщин фертильного возраста в Чечне и Ингушетии. Возрастных матерей (старше 30 лет) в ЧР - 28,5\%, в РИ - 40,5\% (в РИ в 1,5 раза больше, чем в ЧР).

Наиболее благоприятный для первых родов (согласно данным экспертов Всемирной организации здравоохранения) возрастной контингент 20-24 лет составлял в Чечне $34,8 \%$, в то время как в Ингушетии - только $22 \%$ (в 1,5 раза меньше). Средний возраст матерей в РИ был равен 28,5 годам, а средний возраст отцов - еще более "постаревший", он превышал средний возраст матерей на 4,4 года, составляя 33 года (ошибка средней 0,29). Указанные данные являются подтверждением специфики ингушского менталитета: позднего вступления в брак. В России на протяжении многих лет матери до 25 лет составляли 61\% всех рожающих женщин в стране, а средний возраст матерей в 1995 г. был равен 24,5 года (но в 2008 г. достиг 26,6 лет). В Ингушетии имела место возрастная модель по типу "постарения" рождаемости. "Постарение" рождаемости - чрезвычайно важный фактор не только в социологическом и демографическом аспекте, но и в клинической акушерской и перинатальной практике, поскольку поздний возраст женщины является самостоятельным фактором риска развития патологии у матери и плода [3-5]. Анализ состояния заболеваемости беременных, рожениц, родильниц и новорожденных в ЧР и РИ подтверждает вышесказанное.

В связи с тем, что "постарение" рождаемости - этническая специфика Ингушетии, указанная проблема очень актуальна для республики. С 2008 г. в РФ также в возрастной структуре матерей впервые стали превалировать женщины старше 25 лет, а рождаемость у женщин 30 лет и старше возросла в 2 раза. В 2010 г. впервые в Ингушетии был отмечен процесс трансформации возрастной модели рождаемости в сторону омоложения: основным контингентом, формирующим рождаемость, стали женщины от 20 до 25 лет. Возросло и число юных первородящих: с 1,5 до 5,5\% (в 3,5 раза). Матери в Чечне достоверно моложе, чем в Ингушетии, средний возраст матерей в ЧР - 26,6 лет ( $p<0,001)$ и соответствует среднему показателю по РФ.

Таблица 2. Показатели (коэффициент) фертильности женщин в Чеченской Республике и Республике Ингушетия за 6 лет (2005-2010), на 1000 женщин фертильного возраста

\begin{tabular}{|l|c|c|c|c|c|c|}
\hline & $\mathbf{2 0 0 5}$ & $\mathbf{2 0 0 6}$ & $\mathbf{2 0 0 7}$ & $\mathbf{2 0 0 8}$ & $\mathbf{2 0 0 9}$ & $\mathbf{2 0 1 0}$ \\
\hline Чеченская Республика & $\mathrm{X}$ & 72,1 & 79,1 & 91,2 & 91,7 & 96,7 \\
\hline Республика Ингушетия & 46,0 & 47,0 & 52,0 & 57,5 & 58,7 & 39,1 \\
\hline
\end{tabular}

Примечание. X - в 2005 г. в Чеченской Республике не велся статистический учет, в связи с чем отсутствуют медикодемографические данные.

Таблица 3. Возрастные показатели матерей в Чеченской Республике и Республике Ингушетия, полных лет

\begin{tabular}{|c|c|c|c|c|}
\hline \multirow{2}{*}{ Показатели } & \multicolumn{2}{|c|}{ Чеченская республика } & \multicolumn{2}{|c|}{ Республика Ингушетия } \\
\hline & Город & Село & Город & Село \\
\hline Средняя величина & 25,8 & 27,4 & 28,5 & 28,5 \\
\hline Ошибка средней & 0,25 & 0,45 & 0,29 & 0,23 \\
\hline Min & 15 & 16 & 17 & 17 \\
\hline Max & 45 & 48 & 43 & 45 \\
\hline
\end{tabular}


Установлено, что достаточно продолжительные интервалы между родами служат на пользу охране здоровья и помогают выживать новорожденным, младенцам и детям до 5 лет. Эксперты Всемирной организации здравоохранения рекомендуют соблюдать продолжительность интергенетического периода не менее 2-3 лет [4]. Уровень образования влияет на здоровье, уровень младенческой смертности, а также на репродуктивное поведение населения [2, 4, 6, 7]. Исследование состояния и причин младенческой смертности в ЧР и РИ в 2009 г. показало, что от уровня образования зависит и репродуктивное поведение женщин. Так, в ЧР матерей умерших младенцев с начальным образованием (или отсутствием образования) было 60,5\%, со средним и средним специальным - 32\%, а с высшим - всего 7,5\% (табл. 4).

Причиной этому являлся военный конфликт на территории республики, разрушение социальной сферы, в Т.ч. образовательных структур. В РИ несколько иная ситуация: матерей умерших младенцев с начальным образованием (или отсутствием образования) было меньше всего - в 13 раз меньше, чем в ЧР, а с высшим - каждая 4-5-я женщина, что в 3 раза больше, чем в ЧР. В ЧР и РИ роды без соблюдения оптимального интергенетического периода, рекомендуемого Всемирной организацией здравоохранения, т.е. дважды в год и ежегодно, в ЧР составили: $64 \%$ - среди женщин с начальным образованием; 52\% - среди женщин со средним и средним специальным образованием, и только 33\% - у женщин с высшим образованием, среди которых не было зарегистрировано ни одного случая родов 2 раза год. В РИ дважды в год и ежегодно рожали $66,7 \%$ женщин с начальным образованием; 72,9\% - со средним и средним специальным, 81,4\% - с высшим. Обратное соотношение наблюдается по оптимальному интергенетическому периоду (2-3 года). В ЧР из 3 описанных контингентов с разным уровнем образования наиболее чаще придерживались его женщины с высшим образованием и меньше всего с начальным.

Таким образом, установлено, что чем ниже уровень образования женщин в ЧР, тем чаще происходили роды и меньше продолжался интергенетический период. По РИ данная закономерность прослеживалась среди женщин с начальным и средним образованием. Отсутствие закономерности отмечалось в группе женщин с высшим образованием, что, по всей вероятности, связано с более поздним вступлением их в брак, обусловленным годами, потраченными на получение высшего образования, карьерный рост и др., и их желанием быстрее "наверстать" упущенное время.

По оценкам экспертов Всемирной организации здравоохранения, около 50\% всех беременностей относится к числу незапланированных, около $25 \%$ - к нежелатель- ным [8], что крайне актуально для Чечни и Ингушетии. Одна из характерных особенностей обеих республик большое число женщин, имевших 5 и более беременностей. Многорожавшие женщины составляли в ЧР 14\%, в РИ - 16\%, т.е. к данной группе принадлежала каждая 6-7-я родильница (по результатам исследования причин младенческой смертности в ЧР и РИ в 2009 г.). Доказано, что существует взаимосвязь между многочисленными беременностями (от 5 и до 10) и частотой медицинских осложнений [9].

Оптимальным методом сдерживания несбалансированного роста численности населения и уменьшения степени тяжести связанных с ним негативных последствий для экономики и окружающей среды, эффективным способом воздействия на воспроизводство населения на национальном и региональном уровне является планирование семьи. Оно позволяет избежать наступления нежелательной беременности, регулировать интервалы между беременностями, выбор времени рождения ребенка в зависимости от возраста родителей, устанавливать число детей в семье. Планирование семьи помогает снизить уровень материнской смертности, по крайней мере, на 20\%, а детской - на 25\% [10].

Заболеваемость беременных, рожениц, родильниц тесно связана с патологией плода и новорожденного. Наиболее существенные отличия показателей заболеваний и осложнений в период родов и послеродового периода у женщин в ЧР и РИ, по сравнению с показателем по РФ, отмечаются по таким классам болезней, как анемия и кровотечения, частота которых превышает среднероссийский показатель на 1000 родов в 2 и более раза. Особенно выражена патология периода родов. Показатель частоты кровотечений в связи с предлежанием плаценты в РИ превышает показатель по РФ в 2,7 раза, в связи с нарушениями свертываемости крови - в 7,8 раза в ЧР; в связи с отслойкой плаценты - 2,2 раза в ЧР, в 1,3 раза в РИ. Частота акушерских кровотечений относится к категории осложнений в родах, которые характеризуют уровень акушерской помощи, их показатели по Чечне и Ингушетии являются наглядным свидетельством о качестве оказания этого вида помощи. Число женщин с отеками, протеинурией и гипертензивными расстройствами $(206,7 ; 198,7 ; 189,5$ на 1000 родов в ЧР, РИ и РФ, соответственно), мочеполовыми инфекциями (70,5; 141,2; 72,4, соответственно) также превышает средний уровень по РФ.

Перинатальная патология является результатом многофакторного влияния на состояние плода и новорожденного длительности гестационного периода, экстрагенитальной и акушерской патологии матери [11]. В структуре заболеваемости новорожденных на 1000 родившихся живыми в ЧР, РИ и РФ 1-е место занимает патология по классу "Внутриутробная гипоксия и асфиксия при

Таблица 4. Значения интергенетического интервала в зависимости от уровня образования женщин фертильного возраста в Чеченской Республике и Республике Ингушетия в 2009 г.

\begin{tabular}{|c|c|c|c|c|c|c|c|c|}
\hline \multirow{3}{*}{$\begin{array}{c}\text { Уровень } \\
\text { образования }\end{array}$} & \multirow{2}{*}{\multicolumn{2}{|c|}{ Всего женщин, \% }} & \multicolumn{6}{|c|}{ Интервалы между родами у женщин с данным уровнем образования, \% } \\
\hline & & & \multicolumn{2}{|c|}{2 раза в год } & \multicolumn{2}{|c|}{1 год } & \multicolumn{2}{|c|}{ 2-3 года и > } \\
\hline & ЧP & РИ & पP & РИ & ЧР & PИ & पP & РИ \\
\hline Начальное & 60,5 & 4,5 & 20,0 & 66,7 & 44,0 & - & 36,0 & 33,3 \\
\hline Среднее & 32,0 & 71,6 & 4,0 & 12,5 & 48,0 & 60,4 & 48,0 & 27,0 \\
\hline Высшее & 7,5 & 23,9 & - & - & 33,4 & 81,4 & 66,6 & 18,6 \\
\hline
\end{tabular}

Примечание. ЧР - Чеченская Республика, РИ - Республика Ингушетия. 
родах:: 76,3; 229,2 и 98,1, соответственно. В РИ данная патология в 2,3 раза превышает средний показатель по РФ, а в ЧР, наоборот, ниже его. 2-е место в ЧР занимает класс "респираторные нарушения у новорожденных, возникшие в перинатальном периоде" - 52,5; по РИ он занимает 4-е место $(95,2)$. В ЧР данный показатель превышает таковой в среднем по России в 2 раза, в РИ в 1,8 раза (в РФ он равен 41,2 и занимает 5-е место). 3-е место в ЧР и РИ занимает такая распространенная неонатальная патология, как "задержка роста и недостаточность питания»: 40,7 - в ЧР, 126,9 - в РИ (в среднем по РФ - 87,0; 2-е место). Таким образом, в ЧР этот показатель в 2 раза ниже среднего по РФ, а в РИ, наоборот, в 1,5 раза выше. 4-е место в ЧР занимает класс "другие нарушения церебрального статуса" - 27,4, в РИ они занимают 2-е место - 164,9, что в 1,7 раза выше, чем по РФ $(74,5)$. Значительные расхождения между показателями ЧР и РФ отмечаются по классу "Внутриутробные инфекции", которые выявляют у 27,4-36,6\% детей, рожденных живыми, и которые обусловливают от 11 до 45\% гибели детей [12]. Внутриутробные инфекции занимают в ЧР лишь 11-е место - 4,5, что в 3,6 раза меньше показателя по РФ. В Ингушетии данная патология составила 62,7 на 1000 родившихся живыми, что в 3,8 раза выше, чем по РФ. Врожденные пороки развития, являющиеся распространенной патологией неонатального периода, заняли в ЧР 6-е место (17,3), в РИ показатель равен 46,3; это в 1,7 и 1,5 раза меньше среднего показателя по РФ $(30,0)$, соответственно. Низкие показатели заболеваемости в ЧР можно объяснить гиподиагностикой и недоучетом, а также дефицитом кадров. В Ингушетии, по всей вероятности, многие показатели заболеваемости, наоборот, выше в связи с резким ростом заболеваемости и смертности в период военных событий и массовым притоком мигрантов.

Фетоинфантильные потери: структура и причины

С недавнего времени эксперты Всемирной организации здравоохранения признали целесообразным рекомендовать для суммарной оценки репродуктивных потерь внедрение нового учетного показателя - фетоинфантильных (ФИП) или плодово-материнских потерь. Показатель включает в себя и умерших детей в течение первого года жизни (в возрасте от 0 до 365 дней), и мертворожденных, т. е. младенческую смертность и мертворождаемость. Это интегрированный коэффициент, объединяющий информацию о возрастной и причинной структуре смертности плодов и младенцев, в связи с единством значительной части причин этих потерь. Значение данных показателей определяется различными сферами жизнедеятельности общества: с одной стороны, эндогенными причинами (генетическими факторами, исходным состоянием здоровья родителей, здоровья беременной, течением беременности), а с другой - экзогенными факторами (социальноэкономическими условиями жизни, этническими нормами и устоями, психологическими и поведенческими реакциями и медико-организационными дефектами акушерской и перинатальной помощи, обусловливающими предотвратимую патологию ребенка, прежде всего в процессе его рождения) [5]. Динамика показателя репродуктивных потерь (перинатальной, младенческой смертности и др.) в ЧР и РИ является зеркальным отражением состояния всех вышеуказанных факторов.

Средний коэффициент ФИП за 6 лет (2005-2010) составил: в ЧР - 29,6 на 1000 родившихся живыми и мертвыми (в 2,4 раза выше, чем по РФ); в РИ - 27,2, что в 2,2 раза превышает средний показатель по РФ $(12,2)$ (табл. 5). За 6 лет коэффициент ФИП снизился в ЧР на $2,9 \%$, в РИ - на $16 \%$.

Основными показателями, которые рекомендуют эксперты Всемирной организации здравоохранения для оценки качества оказания акушерской и неонатальной помощи, являются: перинатальная смертность, мертворождаемость, ранняя неонатальная смертность, потери беременности в сроки от 22-й нед.

\section{Перинатальная смертность}

Коэффициент перинатальной смертности (средний за 6 лет, с 2005 по 2010 г.) в ЧР составил 21,7, в РИ 20,0 на 1000 родившихся живыми и мертвыми, что

Таблица 5. Структура фетоинфантильных потерь в Чеченской Республике и Республике Ингушетия за $2005-2010$ гг., на 1000 родившихся

\begin{tabular}{|c|c|c|c|c|c|c|}
\hline Показатель потерь & 2005 & 2006 & 2007 & 2008 & 2009 & 2010 \\
\hline \multicolumn{7}{|c|}{ Российская Федерация } \\
\hline Фетоинфантильные потери & 17,2 & 16,0 & 14,9 & $X^{*}$ & $X^{*}$ & 12,2 \\
\hline Младенческая смертность & 11,0 & 10,2 & 9,4 & 8,5 & 8,1 & 7,5 \\
\hline Мертворождаемость & 5,68 & 5,33 & 5,32 & 5,0 & 4,73 & 4,6 \\
\hline \multicolumn{7}{|c|}{ Чеченская Республика } \\
\hline Фетоинфантильные потери & $x$ & 30,8 & 27,5 & 32,8 & 28,8 & 27,9 \\
\hline Младенческая смертность & $x$ & 18,4 & 17,6 & 23,9 & 19,1 & 19,4 \\
\hline Мертворождаемость & $x$ & 12,6 & 10,1 & 9,9 & 10,0 & 8,6 \\
\hline \multicolumn{7}{|c|}{ Республика Ингушетия } \\
\hline Фетоинфантильные потери & 35,0 & 33,5 & 35,6 & 23,4 & 23,2 & 19,0 \\
\hline Младенческая смертность & 24,8 & 24,5 & 27,9 & 15,2 & 15,2 & 12,8 \\
\hline Мертворождаемость & 10,3 & 10,1 & 11,2 & 8,3 & 9,7 & 6,2 \\
\hline
\end{tabular}

Примечание. Фетоинфантильные потери - на 1000 родившихся живыми и мертвыми, младенческая смертность на 1000 родившихся живыми, мертворождаемость - на 1000 родившихся живыми и мертвыми.

X* - в доступных источниках не удалось найти сведения по фетоинфантильным потерям в Российской Федерации в $2008-2009$ гг. X - в 2005 г. в Чеченской Республике не велся статистический учет, в связи с чем отсутствуют медико-демографические данные. 
Таблица 6. Структура и динамика перинатальной смертности в Чеченской Республике, Республике Ингушетия и Российской Федерации в 2005-2010 гг., на 1000 родившихся

\begin{tabular}{|c|c|c|c|c|c|c|c|}
\hline & Коэффициенты & 2005 & 2006 & 2007 & 2008 & 2009 & 2010 \\
\hline \multirow{2}{*}{ PФ } & Перинатальная смертность & 10,17 & 9,57 & 9,07 & 8,30 & 7,81 & 7,4 \\
\hline & Ранняя неонатальная смертность & 4,49 & 4,24 & 3,75 & 3,30 & 3,08 & 2,8 \\
\hline \multirow{2}{*}{ ЧР } & Перинатальная смертность & $x$ & 19,6 & 19,0 & 26,0 & 23,4 & 20,7 \\
\hline & Ранняя неонатальная смертность & $x$ & 8,6 & 9,7 & 16,1 & 13,4 & 12,2 \\
\hline \multirow{2}{*}{ РИ } & Перинатальная смертность & 29,5 & 29,2 & 21,8 & 15,8 & 18,6 & 12,3 \\
\hline & Ранняя неонатальная смертность & 13,4 & 19,1 & 19,2 & 7,6 & 8,9 & 6,0 \\
\hline
\end{tabular}

Примечание. Перинатальная смертность - на 1000 родившихся живыми и мертвыми, ранняя неонатальная смертность на 1000 родившихся живыми; РФ - Российская Федерация, ЧР - Чеченская Республика, РИ - Республика Ингушетия.

X - в 2005 г. в Чеченской Республике не велся статистический учет, в связи с чем отсутствуют медико-демографические данные.

в 2,5 и 2,3 раза выше среднего за 6 лет коэффициента по РФ (8,7), соответственно (табл. 6). Среднегодовая убыль коэффициента перинатальной смертности в ЧР составила 2,6, в РИ - 3,8. В РИ он имел более стабильную динамику до 2008 г., когда он резко снизился в 1,4 раза за счет показателя ранней неонатальной смертности: впервые в республике были созданы отделения реанимации и интенсивной терапии для новорожденных и выездные неонатальные реанимационные бригады, позволившие сохранять жизни детям, которые в прошлом умирали без оказания специализированной помощи, а также в связи с оттоком мигрантов в Чечню (что подтверждается и показателями по Чечне, где перинатальная смертность пропорционально возросла в 1,4 раза). В течение последних 3 лет наметилась тенденция к снижению коэффициента перинатальной смертности в ЧР и РИ. В ее структуре в ЧР превалировала в динамике по годам мертворождаемость (за исключением 2008-2009 гг.), но при оценке среднего показателя за 5 лет преобладала ранняя неонатальная смертность: 12,0 на 1000 родившихся живыми (средний показатель за 6 лет). В Ингушетии, наоборот, стабильно по всем годам преобладает ранняя неонатальная смертность: 12,4 (см. табл. 6).

Коэффициент мертворождаемости в ЧР и РИ в 2 и 1,7 раза выше среднего за 6 лет показателя по РФ, соответственно (5,1\%; среднегодовая убыль МР в ЧР составляет $0,84 \%$, а в РИ $-1,78 \%$ ).

Коэффициент ранней неонатальной смертности (средний за 6 лет, с 2005 по 2010 г.) составлял в ЧР 12,0, в РИ $-11,3 \%$, что в 3,9 и 3,6 раза, соответственно, превышает средний показатель по России за 6 лет $(3,1)$ (см. табл. 6). Основная доля от всех смертей на первом году жизни в ЧР и РИ приходится на ранний неонатальный период: от 50 до 80\% по годам (в РФ - 36,8\% в 2010 г.). Среднегодовой прирост ранней неонатальной смертности в Чечне до 2008 г. составлял в среднем 2,5\%о, а с 2009 г. имеет тенденцию к снижению (1,3\%о).

С 2008 г. коэффициент ранней неонатальной смертности в ЧР резко возрос до максимума (в 1,7 раза), а в Ингушетии, наоборот, резко снизился (в 2,5 раза), что совпало с временем оттока мигрантов обратно в Чечню. Среднегодовая убыль ранней неонатальной смертности в РИ была равна 3,4\%. Ранняя неонатальная смертность заметно выше в ЧР (75,3\%), чем в РИ (60,3\%).

В структуре ранней неонатальной смертности очень высока досуточная летальность новорожденных: в 2010 г. в ЧР $-52,6 \%$, а в РИ $-50 \%$, что в 1,7 раза больше, чем по РФ (30\%). Другими словами, каждый второй новорожденный из числа умерших в ЧР и РИ в возрасте первых 6 сут жизни погиб, не дожив до 24 ч.

В структуре ранней неонатальной смертности в РИ более половины новорожденных были недоношенными (61,2\% в 2010 г.).

Коэффициент младенческой смертности (средний за 6 лет, с 2005 по 2010 г.) составляет: в ЧР - 19,7\%, в РИ - 20,0\%, что в 2 раза превышает аналогичный средний федеральный показатель за 6 лет по РФ (9,1\%о) (см. табл. 5). Максимально высокий показатель младенческой смертности был отмечен в Ингушетии в 2007 г. 27,9\%. В РИ зафиксирована тенденция к снижению показателей младенческой смертности, что связано с причинами, указанными выше (в разделах по перинатальной и ранней неонатальной смертности).

Обращают на себя внимание некоторые различия в соотношении составляющих младенческой смертности в РИ и ЧР. Так, показатель общей неонатальной смертности в РИ преобладает над аналогичным показателем в ЧР: РИ - 77,1 и ЧР - 72,6\%, соответственно, а показатель постнеонатальной смертности, наоборот, выше в ЧР $(27,4 \%)$ по сравнению с РИ $(22,4 \%)$. Постнеонатальная смертность, которая является более управляемой, нежели неонатальная, также все еще имеет достаточно высокий уровень в ЧР.

Представленные данные можно объяснить двумя причинами: высокой досуточной смертностью новорожденных, связанной с низким уровнем репродуктивного и соматического здоровья женщин и рождением больного потомства, а также недостаточно высоким качеством акушерско-гинекологической и реанимационной неонатальной помощи.

Как видно из табл. 7, в структуре причин младенческой смертности по классам в ЧР и РИ лидировал, как обычно, класс "отдельные состояния перинатального периода" - 55,6 и 63,5\%, соответственно. 2-е место занимают врожденные пороки развития и наследственные болезни - 13,6 и 5,1\%. На 3-м месте находятся неуточненные причины и синдром внезапной смерти - 8,7 и 5,5\%. 4-е место в ЧР поделили пневмонии и острые кишечные инфекции - по 4,5\%. В РИ 5-е место заняли острые кишечные инфекции - 2,9\%. Сравнительный анализ характера вскармливания в структуре причин младенческой смертности во взаимосвязи с различными нозологическими формами в ЧР и РИ показал, что в обеих республиках в структуре младенческой смертности большой удельный вес составили управляемые заболевания: острые респира- 
Таблица 7. Структура причин младенческой смертности в Чеченской Республике и Республике Ингушетия в 2009 г., абс. число и процентное отношение

\begin{tabular}{|c|l|c|c|}
\hline № & \multicolumn{1}{|c|}{ Наименование заболевания } & Чеченская Республика, \% & Республика Ингушетия, \% \\
\hline 1 & Отдельные состояния перинатального периода & 55,4 & 63,5 \\
\hline 2 & Врожденные пороки развития, наследственные болезни & 13,6 & 7,1 \\
\hline 3 & Неуточненные причины, синдром внезапной смерти & 8,7 & 4,4 \\
\hline 4 & Пневмонии & 4,5 & 2,9 \\
\hline 5 & Острые кишечные инфекции & 4,5 & 0,7 \\
\hline 6 & Острые респираторные вирусные инфекции & 3,3 & 7,3 \\
\hline 7 & Органическое поражение нервной системы & 3,0 & 2,9 \\
\hline 8 & Несчастные случаи & 2,5 & 2,9 \\
\hline 9 & Внутриутробные инфекции (в постнеонатальном периоде) & 2,1 & 0,7 \\
\hline 10 & Гнойный менингоэнцефалит & 1,2 & 1,5 \\
\hline 11 & Онкологические заболевания & 0,8 & 0,7 \\
\hline 12 & Некротический энтероколит & 0,4 & \\
\hline
\end{tabular}

торные вирусные инфекции, пневмонии, острые кишечные инфекции, менингоэнцефалиты и некротический энтероколит.

Всего умерло детей от 0 до 1 года жизни от управляемых заболеваний: в ЧР - 24,6, в РИ - 13,7\%, т. е. практически каждый 5-й младенец в ЧР и каждый 7-й в РИ.

\section{ЗАКЛЮЧЕНИЕ}

Таким образом, ЧР и РИ отличаются наиболее высокими в РФ естественными воспроизводственными характеристиками: рождаемостью, фертильностью, естественным приростом. Вместе с тем имеют место и высокие показатели младенческой смертности, ФИП, что связано с рядом факторов (политической и социальноэкономической ситуацией, уровнем культурного развития населения, традициями, историческими и этническими особенностями, миграционными процессами и состоянием системы здравоохранения).

Анализ состояния здоровья беременных, рожениц, родильниц и новорожденных в Чечне и Ингушетии показывает, что по многим показателям оно хуже, чем в среднем по России. Одной из важнейших причин этого является низкий уровень акушерской и неонатальной помощи в республиках. Анализ причин низкого уровня соматического и репродуктивного здоровья женщин в период беременности и родов в ЧР и РИ, а также рождающегося потомства показывает, что основными из них являются: избыточная фертильность, несоблюдение оптимального интергенетического периода и возраста деторождения («постарение» рождаемости в РИ), недостаточный уровень образования, низкий уровень планирования семьи.

Планирование семьи очень важно для обеих республик с учетом характерного высокого уровня фертильности при неблагополучной социально-экономической ситуации и высокой материнской и детской заболеваемости и показателей ФИП, что диктует необходимость иного репродуктивного поведения женщин (семей) в современных условиях. Одним из важнейших условий улучшения здоровья женщин репродуктивного возраста и потомства является повышение качества работы службы родовспоможения и детства в обеих республиках.

\section{СПИСОК ЛИТЕРАТУРЫ}

1. Всеобъемлющий обзор и оценка осуществления программы действий международной конференции по народонаселению и развитию. Доклад Специального комитета ООН (Г. Вукович). XXI специальная сессия Генеральной Ассамблеи ООН. Пункт 8 повестки дня, п/п.g. 1999.

2. Рождаемость, репродуктивное здоровье и развитие. Доклад Генерального секретаря ООН. ЮНФПА. 2011. 37 с.

3. Гендерные факторы человеческого развития. Материнское и репродуктивное здоровье. В кн.: Человеческое развитие: Учебник. Гл. 22, параграф 2. Ташкент. 2008. 363 с.

4. Боссерт Т., Баузер Д., Кенни А. и др. Целесообразность планирования семьи в странах бывшего Советского Союза. Региональный проект по планированию семьи в Европе и Евразии. М.: USAID. 2009. C. 6-14, 23-24.

5. Суханова Л.П. Репродуктивный процесс в демографическом развитии России. М.: ФГУ ЦНииОиз Росздрава. 2009. С. 2-4, 9-12, 20-25.

6. Усов И.Н. Здоровый ребенок. Справочник педиатра. Минск. 1984. 201 c.

7. Donnay F. Maternal survival in developing countries: what has been done, what can be achieved in the next decade. Int. J. Gynecol. Obstet. 2000; 70: 89-97.

8. Aliyu M. H., Jolly P. E., Ehiri J. E. et al. High parity and adverse birth outcomes: exploring the maze. Birth. 2005; 32 (1): 45-59.

9. ШроффК. Взаимосвязь между репродуктивным здоровьем и демографической политикой. ЮНФПА. Материалы Конференция женщин-парламентариев ЦА. Душанбе. 2008. 21 с.

10. Соколовская Т.А. Вклад перинатальных причин в формирование детской инвалидности. М.: ФГУ цНИИОИЗ Росздрава. 2008.

11. Макаров О.В., Алешкин В.А., Савченко Т.Я. Инфекции в акушерстве и гинекологии. М.: МЕДпресс-информ. 2007.

12. Сборник МЗиСР РФ "Основные показатели деятельности акушерско-гинекологической службы в РФ". 2010.

13. Сборник МЗиСР РФ “Основные показатели деятельности службы охраны здоровья матери и ребенка в РФ». 2009.

14. Статистический сборник ГКС РИ. 2010.

15. Статистический сборник Росстата. 